\title{
Physico-Chemical Properties of Ordinary Portland Cement Pastes after Partial Substitution of Gypsum With Thermally Treatment Phosphogypsum
}

\author{
a Department of Chemistry,Faculty of Science, Al-Azhar University, Assiut, Egypt \\ ${ }^{b}$ Housing and Building National Research Center, Cairo, Egypt \\ ${ }^{c}$ Manaseer cement and mining company Amman, Jordan, Jordan
}

Mahmoud Ahmed Tahera, (D) , Adel Mohamed Amine ${ }^{b}$, Bassam Khalaf Damarany a,c,*

\section{A R T I C L E I N F O}

Received: 08 July 2019

Revised: 23 July 2019

Accepted: 07 September 2019

Available online: 17 September 2019

\section{K E Y W O R D S}

Phosphogypsum

Clinker

Ordinary Portland cement

\section{A B S T R A C T}

The present study conducted to investigate the potential use of PG in cement industry. This was accomplished by preparing mortar mixes contain Portland cement clinker (PPC) with thermally treated PG at different temperatures (200, $400,600,800$ and $1000^{\circ} \mathrm{C}$ ) instead of raw gypsum (RG) at different proportions. The characteristics of prepared mortars were investigated after curing in water for different periods $(3,7,28$ and 90 days) by determination of setting time, compressive strength, bulk density, and total porosity. The hydration kinetics was evaluated by determination of free lime and chemically combined water contents. FTIR spectroscopic analysis was used to investigate the change in structure of some mortars after curing. The change in morphology and microstructure of hardened pastes was investigated using scanning electron microscopy (SEM). The results approved the possibility for the utilization of treated $\mathrm{PG}$ at 800 and $1000^{\circ} \mathrm{C}$ instead of raw gypsum in cement industry.

G R A P H I C A L A B S T R A C T
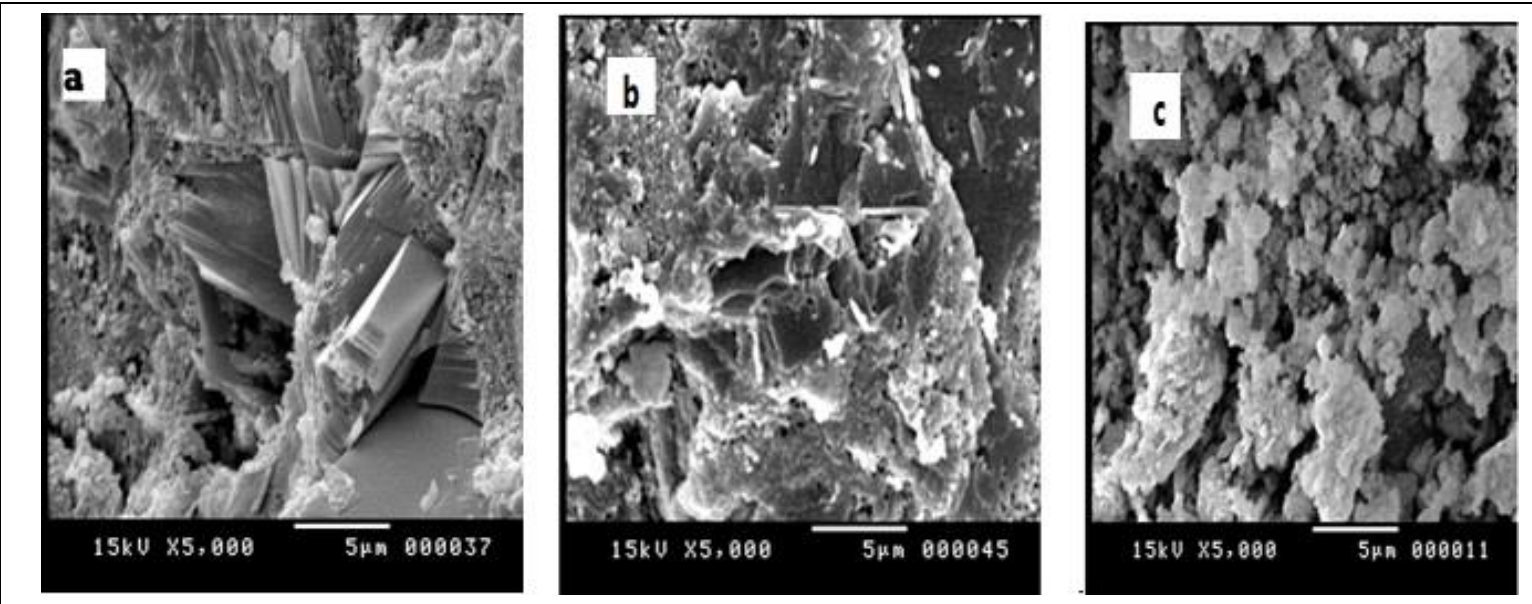

Micrographs of mixes (PV) contain thermally treatment PG at $1000{ }^{\circ} \mathrm{C}$ after $3(\mathrm{a}), 28$ (b) 90 , (c) days curing

\footnotetext{
*Corresponding author's E-mail address: Ch_bassam66@yahoo.com
} 


\section{Introduction}

The chemical and mineralogical characteristics of phosphogypsum vary depending upon the nature of the phosphate ore, the type of process used in fertilizer manufacturing, the efficiency of plant operation, the age and location of the stockpile, and any contaminants which may be introduced into the phosphogypsum at the production plant [1]. Phosphogypsum is the primary by-product generated from the wetacid process for producing phosphoric acid from phosphate rock. Phosphoric acid is an industrial raw material required for the production of phosphate fertilizer. Phosphate rock, mined in open pit mines, does not have a definite chemical composition and the composition varies in different mining areas. Phosphate ore contains roughly one-third quartz sands, one-third clay minerals, and one third phosphate particles, impurities like calcium, fluoride, chlorides, chromium, rare earths and radio nuclides are also common [2]. About 5 tons of PG are generated for every ton of phosphoric acid produced, approximately $85 \%$ of the worldwide $\mathrm{PG}$ byproduct is stockpiled, and $15 \%$ is reprocessed [3]. Therefore, attempts were made to use PG in concrete [4]. A large volume of natural gypsum is used by the cement industry as a set retarder for OPC. It is added to the clinker at the cement grinding stage, usually at a concentration of 5-6\%, depending on its purity [5]. The use of PG to replace natural gypsum in OPC is minimal, and the main reason for the low demand is its high moisture content and impurities, which interfere with the consistency of the cement [6]. The phosphorus, sulfate, fluoride, and organic impurities contained in PG interfere in an unpredictable way to delay the setting time, and decrease the mechanical strength development of cement [7]. Although, treated phosphogypsum can be used as an ingredient of plaster [8-10]. The most important and motivating use of phosphogypsum could be in the construction industry. In the manufacturing process of cement, phosphogypsum could be used as a replacement of natural gypsum which plays the role of a set retarder $[11,12]$, or to reduce the clinkerization temperature [13]. Previous studies have focused on reducing impurity levels in PG [14]. Heat treatment has been mostly used to obtain an anhydrite phase for use in building and road construction materials [15-18]. PG is one of the most serious problems facing the phosphate industry, since only $15 \%$ of the world production is recycled as an agricultural fertilizer, a building material or a soil stabilization amendment [19]. The remaining $85 \%$ of $P G$ is dumped in the vicinity of phosphate factories, requiring large disposal areas. PG dumping causes soil, water and air pollution. The main problems associated with the accumulation of PG without any treatment are the relatively high levels of natural uranium-series radionuclides and the leachability of hazardous elements [20]. However, with higher percentage of phosphogypsum, the strength of concrete mixtures is affected by the moisture at the time of testing. Better compressive strength attained with calcined phosphogypsum [16]. Study with up to $40 \%$ cement replacement by phosphogypsum gave $10 \%$ level optimum [21]. G.M. Sadiqul Islama et al. [22] found that, the processing of phosphogypsum gave better performance in all media. Processed sample gave better or at least similar performance than the control samples (100\% clinker) in paste, mortar and concrete at $10 \%$ addition level. This indicated that the industrial byproduct could sustainably be used as replacement of natural gypsum (generally used $5 \%$ of total cement) in cement manufacturing. On the other hand, the possible use of PG as a major constituent in construction materials is vital in order to solve the serious negative environmental 
impacts caused by the dispersion of the harmful chemicals contained in PG into surrounding environment. M. Taher et al. [23] studied Physico-chemical properties of Portland Pozzolanic cement paste after partial substitution of gypsum with thermally treatment phosphogypsum at different temperatures $(200,400,600,800$ and 1000 ${ }^{\circ} \mathrm{C}$ ) and found that Phosphogypsum can be economically used up to five percent as an ingredient in Pozzolanic Portland cement, This will eliminate a serious environmental source of pollution; besides, it will decrease the cost of cement production. It is also recommended that further investigations be executed to explore the possibility of extracting gypsum from PG that can be used directly in cement industry. The addition of treated PG at different temperature leading to improvement of physio-chemical properties. Several studies were carried out on purifying the PG by washing it with water to minimize the impurities content before utilizing it in various industrial aspects. To enlighten the environmental concerns of the huge $P G$ stockpiled at the industrial complex at Jordan, this study aims to examine the possible utilization of these treated PG wastes replacing the expensive pure gypsum in cement industry, presenting the best scenario and mixing ratios to attain the best cement mortar properties.

\section{Experimental}

\section{Materials}

Portland Cement Clinker (PCC) and raw gypsum (RG) used in the present experimental study, have been obtained from Manaseer Cement Company (Jordan). The Clinker was procured from local market and in one lot to maintain uniformity throughout the investigation. Phosphogypsum (PG) was produced as by-products of phosphoric acid manufacture process in Jordan Abyad Fertilizers and Chemicals Company (Jordan).
The chemical compositions of starting materials and PG after different firing temperatures are given in Table 1. It was clear from thermal treatment of $\mathrm{PG}$ that , $\mathrm{CaO} \%$ increased by increasing firing temperature and value of $\mathrm{CaO}$ content reach to $40.53 \%$ at $1000{ }^{\circ} \mathrm{C}$ higher than or immediate equal raw gypsum $\mathrm{CaO}$ Content ( 39.8\%). Also, it was clear that $\mathrm{SiO}_{2}$ content reach to $10.52 \%$ at this firing temperature and $\mathrm{P}_{2} \mathrm{O}_{5} \%, \mathrm{SO}_{3} \%$ values decreased to $2.35 \%$ and $33.1 \%$, respectively, indicating the useful effect of thermal treating of PG for using instead of RG in production of Portland cement. The mix compositions of the prepared OPC with mix numbers are given in Table 2.

\section{Methods and instruments}

Phosphogypsum used in this study was obtained from Jordan Abyad Fertilizers and Chemicals Company, Jordan. Thermal treatment of PG has been done by heating $2 \mathrm{~h}$ $\left(10{ }^{\circ} \mathrm{C} / \mathrm{min}\right)$ in muffle furnace for the required temperatures in this investigation 200,400 , 600,800 and $1000{ }^{\circ} \mathrm{C}$. After every calcined temperature, PG was cooled in room temperature, crushed and ground in jaw crusher machine. The chemical composition and mineralogical constituents of Portland cement clinker (PCC), Phosphogypsum (PG), and Raw Gypsum (RG) which illustrated in Table 1 have been done using XRF 9900, all these materials were separately crushed and ground in the jaw crusher machine. The ingredients of each mix were blended in the lab ball mill for $2 \mathrm{~h}$ to insure complete homogeneity. The preparation of mixes was made according to EN-196-1 [24]. Specimens were cast into mold of $(2.54 \times 2.54 \mathrm{~cm})$, then the specimens in the mold are stored curing in humidity chamber at $20 \pm 1{ }^{\circ} \mathrm{C}$ for $24 \mathrm{~h}$ then demolded and immersed in tap water until tested. After the predetermined curing time 3 , 7,28 and 90 days, groups of three specimens were used to determine the residual compressive strength. 
Table 1. Chemical composition of stating materials (mass \%)

\begin{tabular}{|c|c|c|c|c|c|c|c|c|}
\hline Contents & PCC & $\begin{array}{l}\text { PG before } \\
\text { Firing }\end{array}$ & $\begin{array}{c}\mathrm{PG} \text { at } \\
200^{\circ} \mathrm{C}\end{array}$ & $\begin{array}{c}\mathrm{PG} \text { at } \\
400{ }^{\circ} \mathrm{C}\end{array}$ & $\begin{array}{l}\mathrm{PG} \text { at } \\
600{ }^{\circ} \mathrm{C}\end{array}$ & $\begin{array}{l}\mathrm{PG} \text { at } \\
800{ }^{\circ} \mathrm{C}\end{array}$ & $\begin{array}{c}P G \text { at } \\
1000^{\circ} \mathrm{C}\end{array}$ & $\mathrm{RG}$ \\
\hline $\mathrm{CaO} \%$ & 64.48 & 35 & 35.12 & 35.8 & 36.71 & 37.5 & 40.53 & 39.82 \\
\hline $\mathrm{SiO} 2 \%$ & 21.32 & 8.32 & 8.48 & 8.56 & 9.07 & 9.50 & 10.52 & 6.81 \\
\hline $\mathrm{AL}_{2} \mathrm{O}_{3} \%$ & 5.32 & 0.15 & 0.16 & 0.33 & 0.56 & 0.29 & 0.25 & 1.1 \\
\hline $\mathrm{Fe}_{2} \mathrm{O}_{3} \%$ & 3.78 & 0.17 & 0.15 & 0.2 & 0.16 & 0.16 & 0.15 & 0.56 \\
\hline $\mathrm{MgO} \%$ & 2.08 & 0.42 & 0.42 & 0.45 & 0.47 & 0.482 & 0.2 & 1.59 \\
\hline $\mathrm{K}_{2} \mathrm{O} \%$ & 0.58 & 0.04 & 0.04 & 0.04 & 0.036 & 0.043 & 0.003 & 0.35 \\
\hline $\mathrm{Na}_{2} \mathrm{O} \%$ & 0.58 & $\cdots$ & 0.1 & ..... & ..... & ...... & 0.74 & 0.01 \\
\hline SO3 \% & 0.89 & 42.06 & 39 & 35.32 & 33.63 & 36.21 & 33.1 & 22.18 \\
\hline $\mathrm{P}_{2} \mathrm{O}_{5} \%$ & 0.33 & 6.79 & 6.44 & 3.94 & 3.77 & 2.55 & 2.35 & 0.39 \\
\hline $\mathrm{Cl} \%$ & 0.002 & ...... & 0.01 & $\ldots$. & 0.28 & 0.34 & 0.43 & 0.02 \\
\hline LOI \% & 0.00 & 10.1 & 9.63 & 7.43 & 3.6 & 1.01 & 0.82 & 31.04 \\
\hline $\mathrm{Cr}_{2} \mathrm{O}_{3} \%$ & 0.011 & $\cdots$ & $\cdots$ & ..... & $\cdots$ & $\ldots$ & $\ldots$ & $\cdots \cdot$ \\
\hline $\mathrm{TiO}_{2} \%$ & 0.56 & 0.054 & 0.056 & 0.054 & 0.052 & 0.047 & 0.052 & 0.12 \\
\hline $\mathrm{Mn}_{2} \mathrm{O}_{3} \%$ & 0.022 & $\ldots$ & $\ldots \ldots$ & $\ldots$ & $\ldots$ & $\ldots$ & $\ldots$ & ........ \\
\hline $\mathrm{ZnO} \%$ & 0.000 & 0.045 & 0.015 & 0.045 & 0.048 & 0.037 & 0.018 & 0.008 \\
\hline SrO \% & 0.045 & 0.46 & 0.29 & 0.52 & 0.55 & 0.47 & 0.333 & 0.35 \\
\hline
\end{tabular}

Table 2. Mix compositions and mixes number of prepared OPC (mass \%)

\begin{tabular}{cc} 
Mix No & Mix Composition \\
P & $95 \%$ PCC + 5\% RG (blank) \\
PI & $95 \%$ PCC + 4\% RG + 1\% PG \\
PII & $95 \%$ PCC + 3\% RG +2\% PG \\
PIII & $95 \%$ PCC + 2\% RG + 3\% PG \\
PIV & $95 \%$ PCC + 1\% RG + 4\% PG \\
PV & $95 \%$ PCC + 5\% PG \\
\hline
\end{tabular}

PCC: Portland Clinker Cement PG: Phosphogypsum RG: Raw Gypsum

Setting times of cements mixed by mixing different proportions were measured by Vicat apparatus according to EN-196-3 [25]. Bulk density and total porosity were determined after any time of hydration as described elsewhere [26]. The hydration of cement pastes were stopped by employing alcoholether method [27]. The samples were dried at $105{ }^{\circ} \mathrm{C}$ for $1 \mathrm{~h}$ and then collated in polyethylene bags; sealed and stored in desiccators for analysis. The degree of hydration was followed by determination of free lime [29] and chemically combined water contents [30]. The raw materials characterized by XRF (Fluorescence (XRF thermo scientific ARL 9900 Total Cement Analyzer) and the change in structure of mortars after curing characterize by FTIR 
spectroscopic (a Perkin-Elmer System 2000 FTIR spectrometer) and scanning electron microscopy SEM (JEOL JSM-840 SEM) were used for investigate and change in morphology and microstructure of some hardened pastes, finally the compressive strength of hardened pastes determined by the digital compressive strength machine (Toni/ technik).

\section{Results and Discussion}

\section{Water of consistency and setting time}

Water of consistency of mortars were illustrated in Figure 1. It was clear that, water/cement ratio decreases with increasing PG percentages from $1 \%$ to $5 \%$, on the other hand, the water/cement ratio for OPC with raw gypsum is $24.3 \%$ is higher than OPC with PG. However, at temperature $200{ }^{\circ} \mathrm{C}$ and 400 ${ }^{\circ} \mathrm{C}$ the water/cement ratio decrease gradually reached to $22.2 \%$ with replacement of $P G$ this due to PG possess anhydrite water demand than raw gypsum. By increasing firing temperature $\mathrm{PG}$ reached to $600{ }^{\circ} \mathrm{C}$, the water/cement ratio decreases gradually reached to $22.6 \%$. The pastes containing PG fired at $800{ }^{\circ} \mathrm{C}$ possess the highest water of consistency value $23.7 \%$. By increasing firing temperature of $\mathrm{PG}$ to $1000{ }^{\circ} \mathrm{C}$ the water/cement ratio decreases to $22.2 \%$. The initial and final setting time of OPC pastes containing PG treated at $200 \& 400 \& 600 \&$ 800 and $1000{ }^{\circ} \mathrm{C}$ were given in Table 3 . It was clear that initial and final setting time increased with increasing PG contents at low values of thermal treating temperatures of $P G$ and decreased by increasing thermal temperature. All mixes possesses initial and final setting time closed to the blank sample (P) at 800 and $1000{ }^{\circ} \mathrm{C}$. The reasons of all these results are attributed to thermal treatment of PG which decreases the pronounced effect of water soluble $\mathrm{P}_{2} \mathrm{O}_{5}$ and present phosphorus, sulfate, fluoride, and organic impurities contained in PG interfere in an unpredictable way to delay the setting time in PG [7]. Form protective coating as by the impurities on the surface of cement grains during the gauging of cement with water and thus suppression of the hydration of cement temporarily [31].

\section{Compressive strength}

The compressive strength results obtained for the various Ordinary Portland cement pastes (PI-PV) containing different percentage of thermally treated $P G$ at different temperatures $(200,400,600,800$ and $1000{ }^{\circ} \mathrm{C}$ ) and blank sample (P) as a function of curing time are graphically shown in Figures 2-6, respectively.
Figure 1. Water of consistency of mixes (PI-PV) at different thermal treatment temperatures of PG

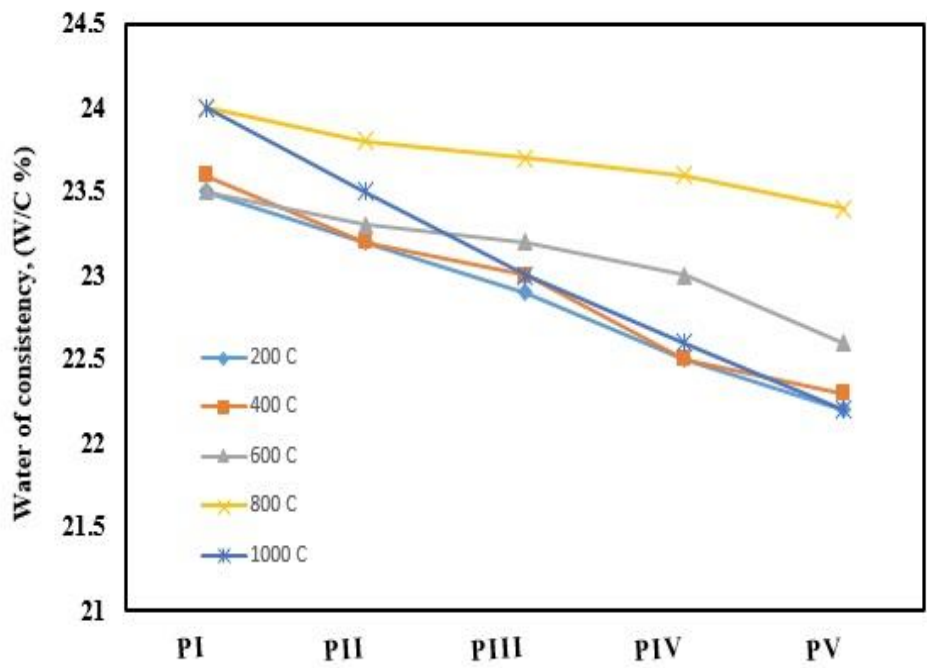


The compressive strength values increased continuously with increasing age of hydration. As the hydration proceeds, the amount of hydration products increase and their accumulation closes the available pore volumes, and this leads to the decrease of total porosity and finally, increases the compressive strength with time. It was clear that, substitution of RG by thermally treated $\mathrm{PG}$ at 800 and $1000^{\circ} \mathrm{C}$ causes increasing in the compressive strength than the blank sample (P) for all mixes (PI-PV) and for all curing time. This is attributed to increasing calcination temperature of PG causes decreasing in $\mathrm{P}_{2} \mathrm{O}_{5}$ contents and also there is increasing in $\mathrm{CaO}, \mathrm{SiO}_{2}, \mathrm{Al}_{2} \mathrm{O}_{3}, \mathrm{Fe}_{2} \mathrm{O}_{3}$ contents which causes increasing in rate of hydration. Mixes PV containing PG thermally treated at 800 and $1000{ }^{\circ} \mathrm{C}$ possess the higher compressive strength values after 90 days curing.

Accordingly, increasing heat treatment (calcination) of $\mathrm{PG}$ and its percentage in mortars improved the mechanical properties of Ordinary Portland Cement. Mixes PV contain $5 \%$ thermally treated $\mathrm{PG}$ at 800 and $1000{ }^{\circ} \mathrm{C}$ possessed higher compressive strength values but mix PV possessed the highest value.

Table 3. Initial and final setting time of mixes (PI-PV) containing thermal treated PG at different temperatures

\begin{tabular}{|c|c|c|c|c|c|c|c|c|c|c|}
\hline \multirow[b]{2}{*}{ Mix } & \multicolumn{2}{|c|}{$200{ }^{\circ} \mathrm{C}$} & \multicolumn{2}{|c|}{$400^{\circ} \mathrm{C}$} & \multicolumn{2}{|c|}{$600^{\circ} \mathrm{C}$} & \multicolumn{2}{|c|}{$800^{\circ} \mathrm{C}$} & \multicolumn{2}{|c|}{$1000^{\circ} \mathrm{C}$} \\
\hline & $\begin{array}{l}\text { Initial } \\
\text { (min) }\end{array}$ & $\begin{array}{l}\text { Final } \\
\text { (min) }\end{array}$ & $\begin{array}{l}\text { Initial } \\
\text { (min) }\end{array}$ & $\begin{array}{l}\text { Final } \\
\text { (min) }\end{array}$ & $\begin{array}{l}\text { Initial } \\
\text { (min) }\end{array}$ & $\begin{array}{l}\text { Final } \\
\text { (min) }\end{array}$ & $\begin{array}{l}\text { Initial } \\
\text { (min) }\end{array}$ & $\begin{array}{l}\text { Final } \\
\text { (min) }\end{array}$ & $\begin{array}{l}\text { Initial } \\
\text { (min) }\end{array}$ & $\begin{array}{l}\text { Final } \\
\text { (min) }\end{array}$ \\
\hline PI & 515 & 585 & 540 & 630 & 360 & 430 & 195 & 270 & 185 & 250 \\
\hline PII & 630 & 690 & 675 & 760 & 585 & 645 & 200 & 275 & 195 & 265 \\
\hline PIII & 700 & 820 & 830 & 896 & 780 & 850 & 215 & 305 & 200 & 275 \\
\hline PIV & 680 & 825 & 860 & 940 & 720 & 790 & 205 & 280 & 205 & 285 \\
\hline PV & 710 & 790 & 770 & 850 & 615 & 695 & 210 & 295 & 205 & 290 \\
\hline$P$ & 205 & 285 & & & & & & & & \\
\hline
\end{tabular}

Figure 2. Compressive strength of hardened pastes made from mixes (PI-PV) containing thermally treated $\mathrm{PG}$ at $200{ }^{\circ} \mathrm{C}$ after $3,7,28$ and 90 days curing

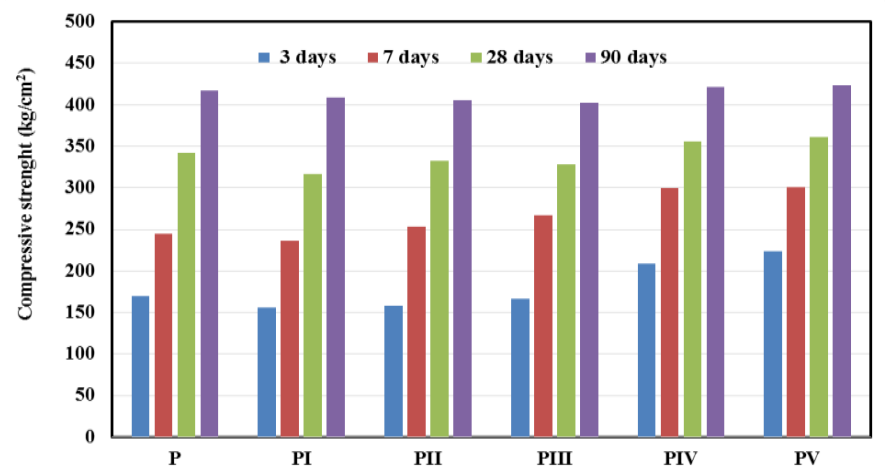

Figure 3. Compressive strength of hardened pastes made from mixes (PI$\mathrm{PV}$ ) containing thermally treated $\mathrm{PG}$ at $400{ }^{\circ} \mathrm{C}$ after $3,7,28$ and 90 days curing

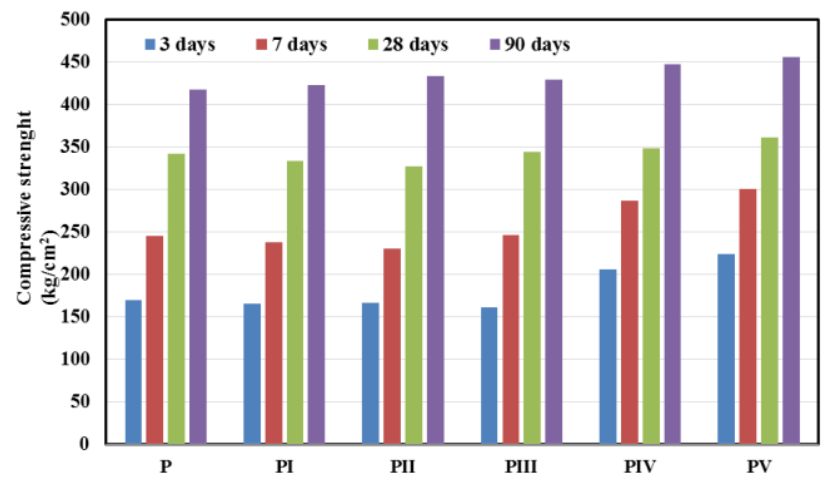


Figure 4. Compressive strength of hardened pastes made from mixes (PIPV) containing thermally treated $P G$ at $600^{\circ} \mathrm{C}$ after $3,7,28$ and 90 days curing

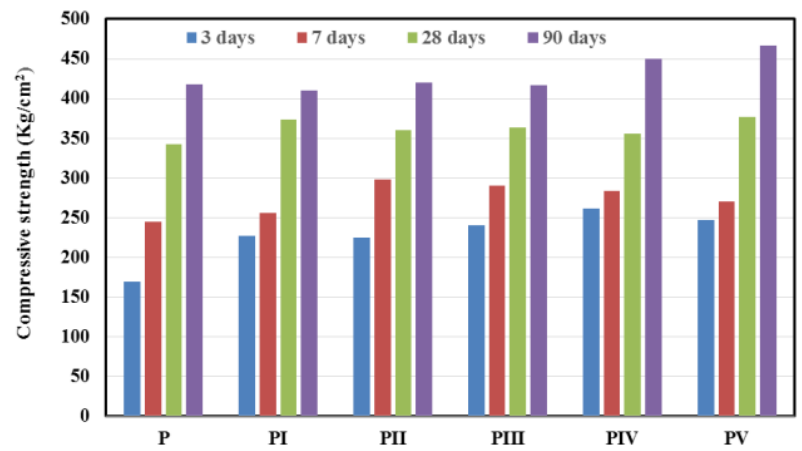

Figure 5. Compressive strength of hardened pastes made from mixes (PIPV) containing thermally treated PG at $800^{\circ} \mathrm{C}$ after $3,7,28$ and 90 days curing

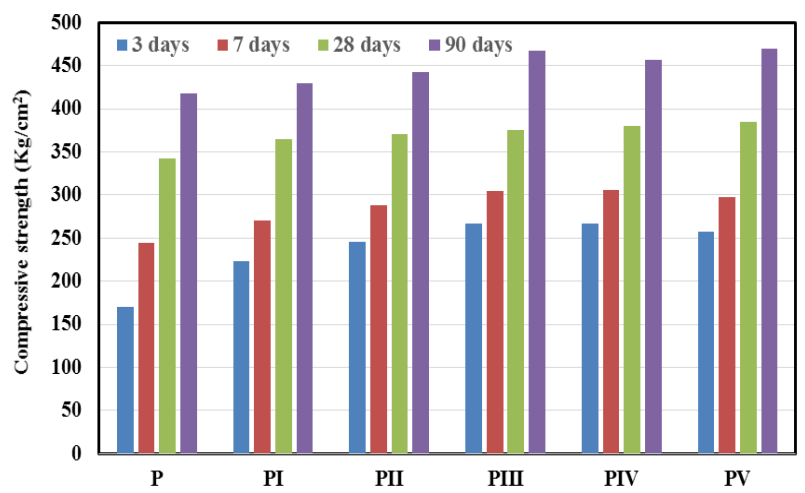

\section{Bulk density and total porosity}

Bulk density is an important factor in the determination of porosity, assessment of durability and strength and estimation of lattice constants for CSH phase in hydrated Portland cement. As the hydration of cement progresses the hydration products fill some of pores because the volume of hydration products is more twice than that of the anhydrous cement; this decreases the porosity and increases the bulk density of hardened cement paste. Figures 7-11, shown that the bulk density of OPC which containing PG treated at different temperature $\left(200,400,600,800\right.$ and $\left.1000{ }^{\circ} \mathrm{C}\right)$ increases by curing time in all mixes. This is mainly due to the progress of the cement pastes especially $\beta$ $\mathrm{C}_{2} \mathrm{~S}$ which is the main phase. Porosity can govern the properties of the materials, especially affecting material strength. High porosity will result in low material strength, whereas decreasing porosity can enhance material strength [31,32]. Results in Figures 1216 , indicated that the total porosity for all samples OPC contain firing PG at different temperature decreases gradually for long time, on the contract all samples possess high porosity at 3 days and the lowest total porosity at 90 days [33].

Figure 6. Compressive strength of hardened pastes made from mixes (PI-PV) containing thermally treated $\mathrm{PG}$ at $1000{ }^{\circ} \mathrm{C}$ after 3, 7, 28 and 90 days curing

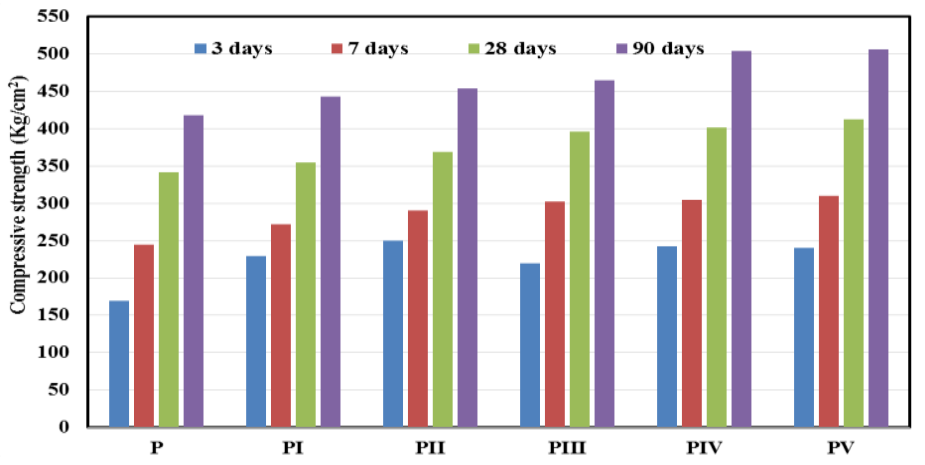


Figure 7. Bulk density $\left(\mathrm{g} / \mathrm{cm}^{3}\right)$ hardened pastes made from mixes (PI-PV) containing thermally treated $\mathrm{PG}$ at $200{ }^{\circ} \mathrm{C}$ after $3,7,28$ and 90 days curing

Figure 8. Bulk density $\left(\mathrm{g} / \mathrm{cm}^{3}\right)$ hardened pastes made from mixes (PI-PV) containing thermally treated $\mathrm{PG}$ at $400{ }^{\circ} \mathrm{C}$ after 3, 7, 28 and 90 days curing

Figure 9. Bulk density $\left(\mathrm{g} / \mathrm{cm}^{3}\right)$ hardened pastes made from mixes (PI-PV) containing thermally treated PG at $600{ }^{\circ} \mathrm{C}$ after $3,7,28$ and 90 days curing
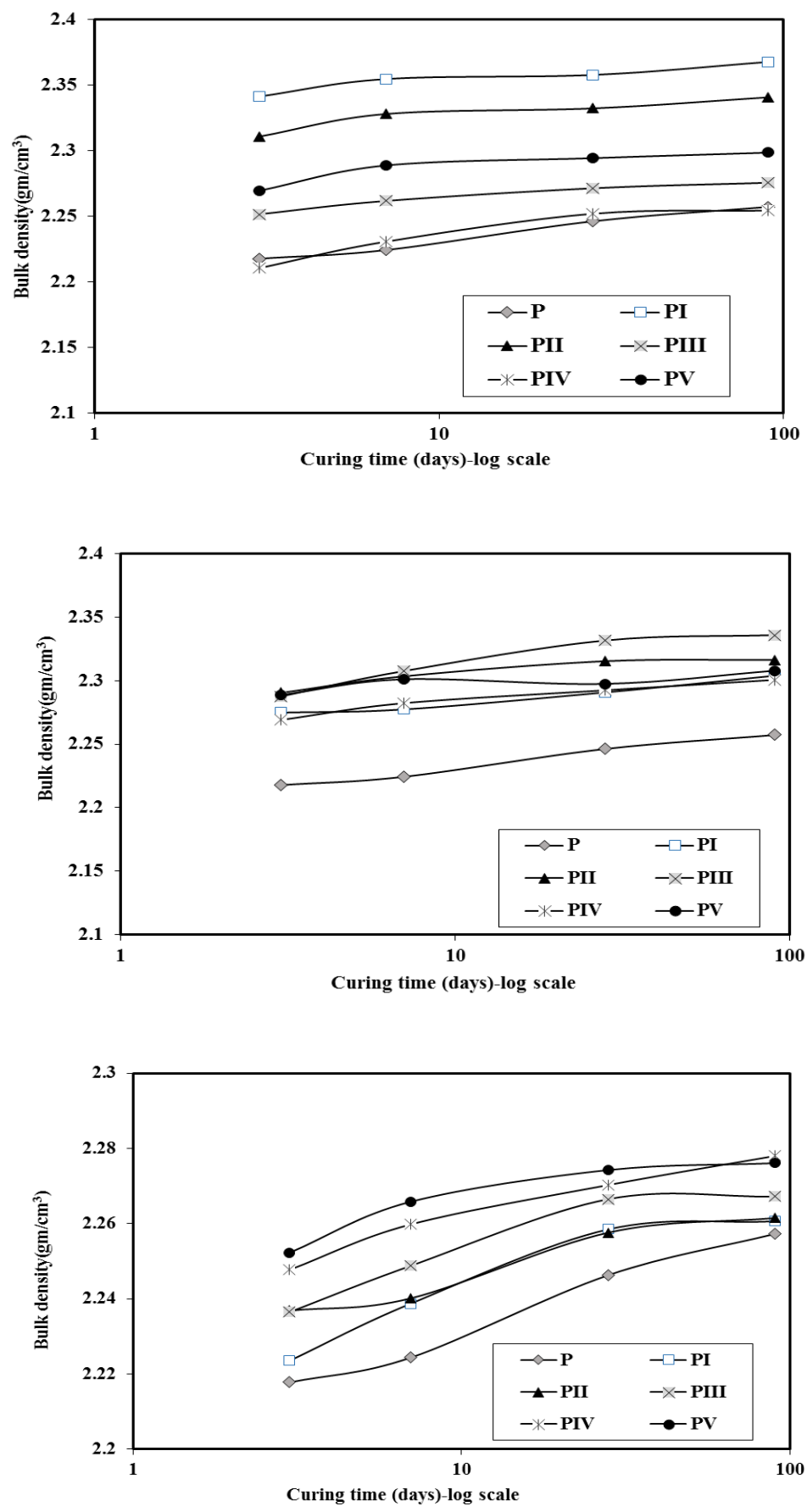

Figure 10. Bulk density $\left(\mathrm{g} / \mathrm{cm}^{3}\right)$ hardened pastes made from mixes (PI-PV) containing thermally treated $\mathrm{PG}$ at $800^{\circ} \mathrm{C}$ after $3,7,28$ and 90 days curing

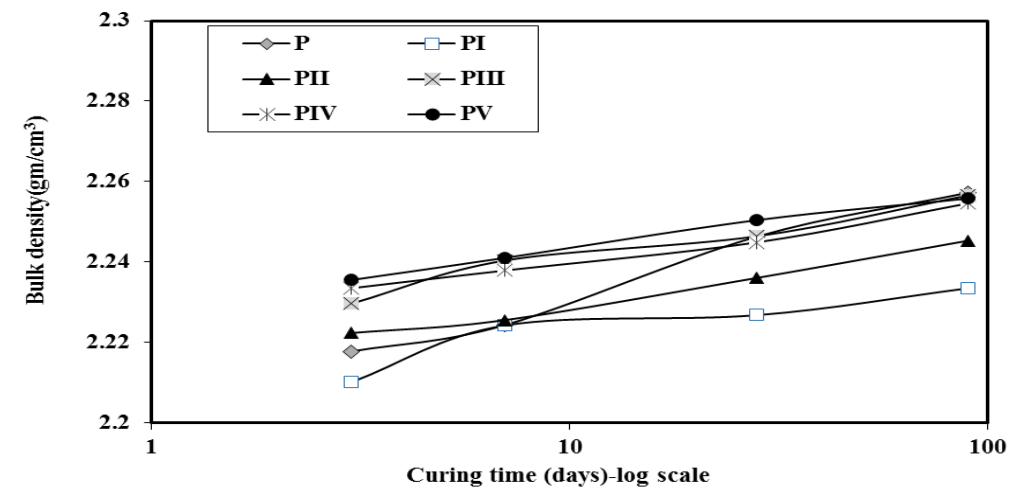


Figure 11. Bulk density $\left(\mathrm{g} / \mathrm{cm}^{3}\right)$ hardened pastes made from mixes (PI-PV) containing thermally treated PG at $1000{ }^{\circ} \mathrm{C}$ after $3,7,28$ and 90 days curing

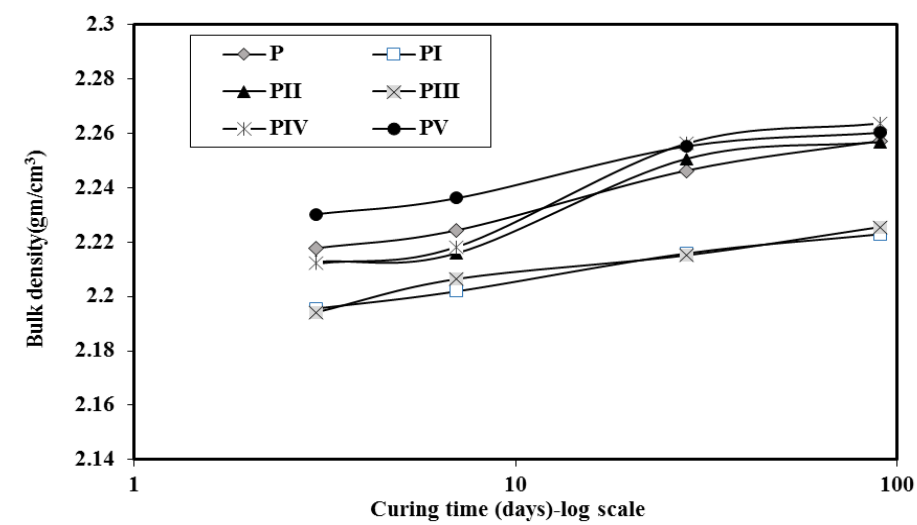

Figure 12. Porosity (\%) hardened pastes made from mixes (PI-PV) containing thermally treated PG at $200{ }^{\circ} \mathrm{C}$ after 3, 7, 28 and 90 days curing

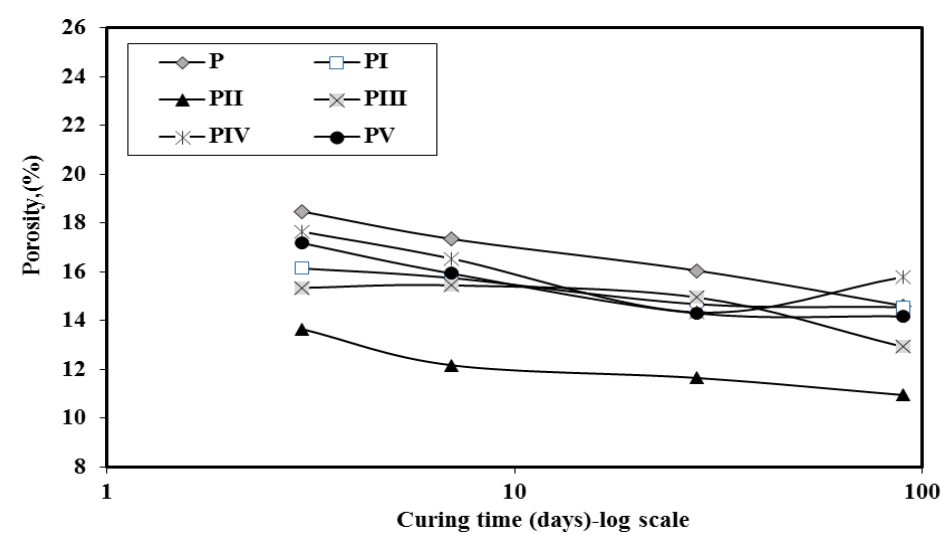

Figure 13. Porosity (\%) hardened pastes made from mixes (PI-PV) containing thermally treated $\mathrm{PG}$ at $400{ }^{\circ} \mathrm{C}$ after $3,7,28$ and 90 days curing

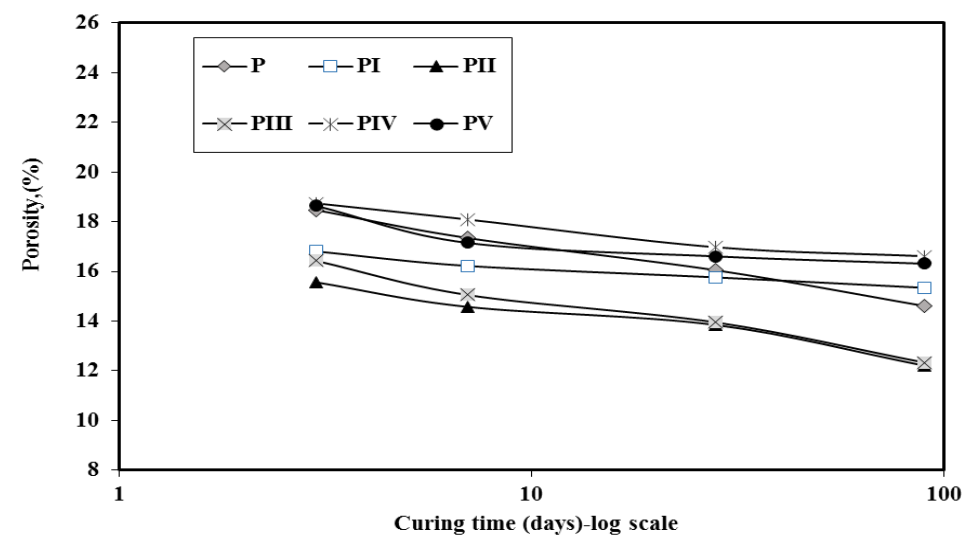

Figure 14. Porosity (\%) hardened pastes made from mixes (PI-PV) containing thermally treated $\mathrm{PG}$ at $600{ }^{\circ} \mathrm{C}$ after $3,7,28$ and 90 days curing

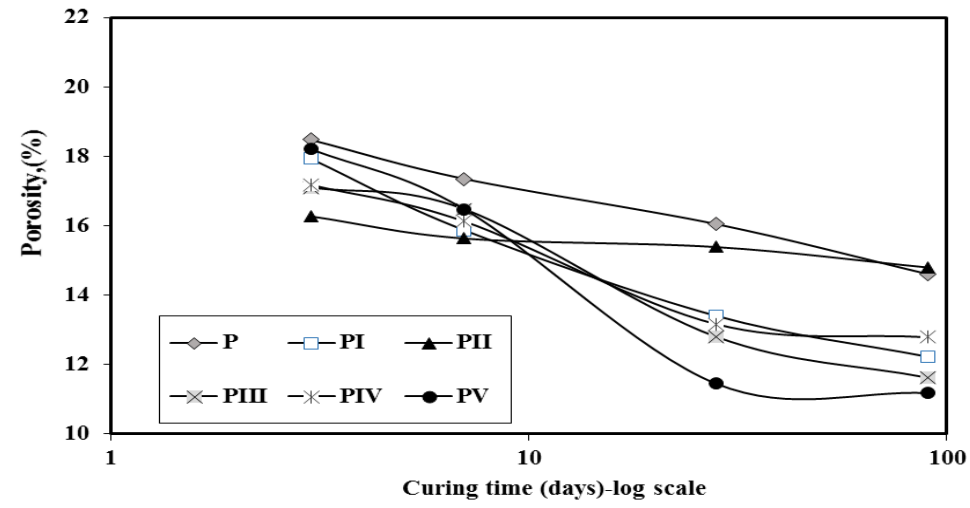


Figure 15. Porosity (\%) hardened pastes made from mixes (PI-PV) containing thermally treated $\mathrm{PG}$ at $800{ }^{\circ} \mathrm{C}$ after $3,7,28$ and 90 days curing

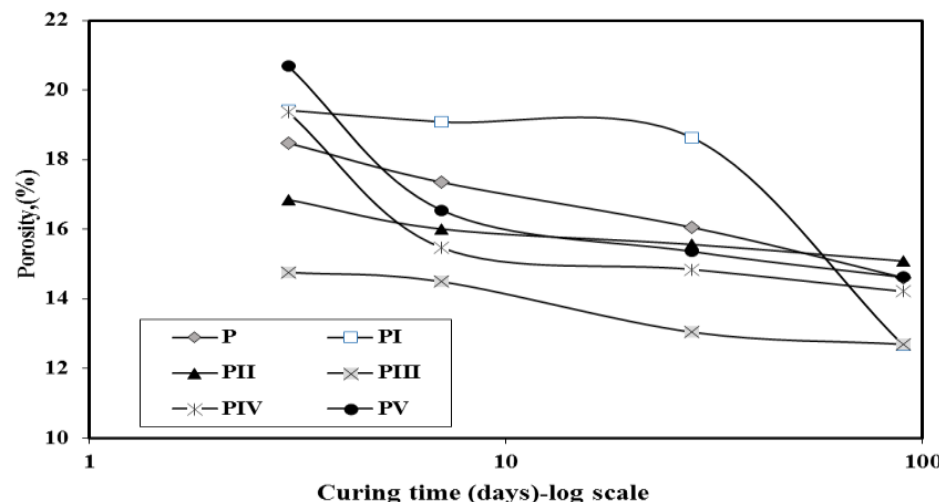

Figure 16. Porosity (\%) hardened pastes made from mixes (PI-PV) containing thermally treated $\mathrm{PG}$ at $1000{ }^{\circ} \mathrm{C}$ after $3,7,28$ and 90 days curing

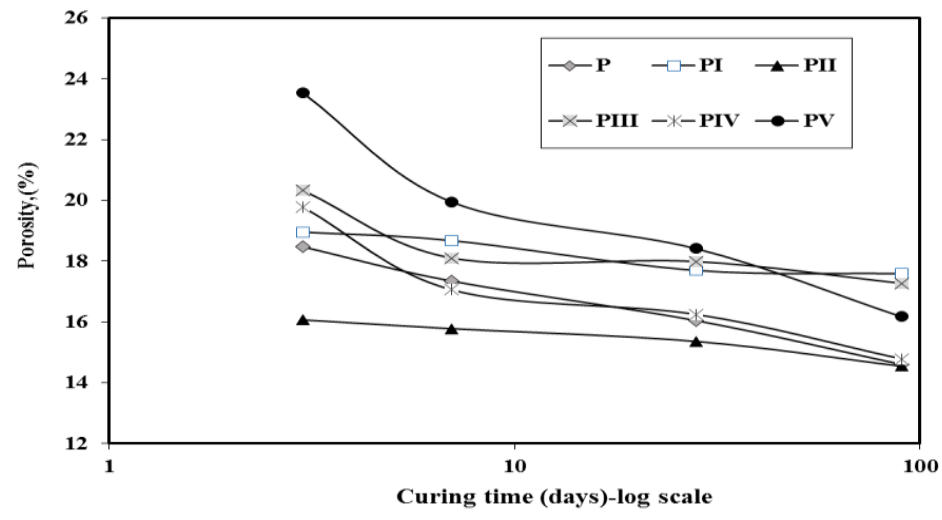

\section{Chemically- combined water content (\%)}

From another point of view, also we studied the chemically-combined water contents. Figures 17-21, shown Chemically-combined water contents $(\mathrm{Wn} \%)$ of hardened specimens made from OPC and PG (treated at different temperature) as a function of curing time, the combined water increases with increasing curing time for all pastes at 3, 7, 28 and 90 days. So the highest combined water at 90 days for all samples this is due to Calcium hydroxide contributes slightly to the strength and impermeability of the paste, because it reduces the total pore volume by converting some of the liquid water into solid form. In this respect it is much less important than the $\mathrm{C}-\mathrm{S}$-H however, $\mathrm{CH}$ is the most soluble of the hydration products and thus is a weak link in cement and concrete from a durability point of view. If the paste is exposed to fresh water, the $\mathrm{CH}$ will leach out (dissolve), increasing the porosity and thus making the paste more vulnerable to further leaching and chemical attack. Calcium hydroxide is believed to play a role in limiting the amount of shrinkage that occurs when a cement paste is dried. As water is removed from the pore system, the C-S-H gel phase collapses causing an overall shrinkage, while other crystalline phases such as $\mathrm{CH}$ are unaffected. As the $\mathrm{C}-\mathrm{S}-\mathrm{H}$ starts to shrink the $\mathrm{CH}$ that is in contact with it acts as a restraint, so that the overall shrinkage is less than it would be if the $\mathrm{CH}$ were not present. As the $\mathrm{CH}$ that forms from cement hydration is consumed along with the mineral admixtures to form additional C-S-H gel. This has beneficial effects on the strength and permeability, but tends to increase the tendency for drying shrinkage for the reasons mentioned above. Consequently, the results of chemically combined water contents indicated that mixes PI (contain PG treated at $800{ }^{\circ} \mathrm{C}$ ) have the highest combined water contents in OPC-PG mixes but have the lowest effective hydrated phases, while mixes PIV and PV(contain PG treated at $1000{ }^{\circ} \mathrm{C}$ ) have the lowest combined water contents and highest effective hydrated phases. 
Figure 17. Chemicallycombined water contents (Wn\%) hardened pastes made from mixes (PI-PV) containing thermally treated PG at $200{ }^{\circ} \mathrm{C}$ after $3,7,28$ and 90 days curing

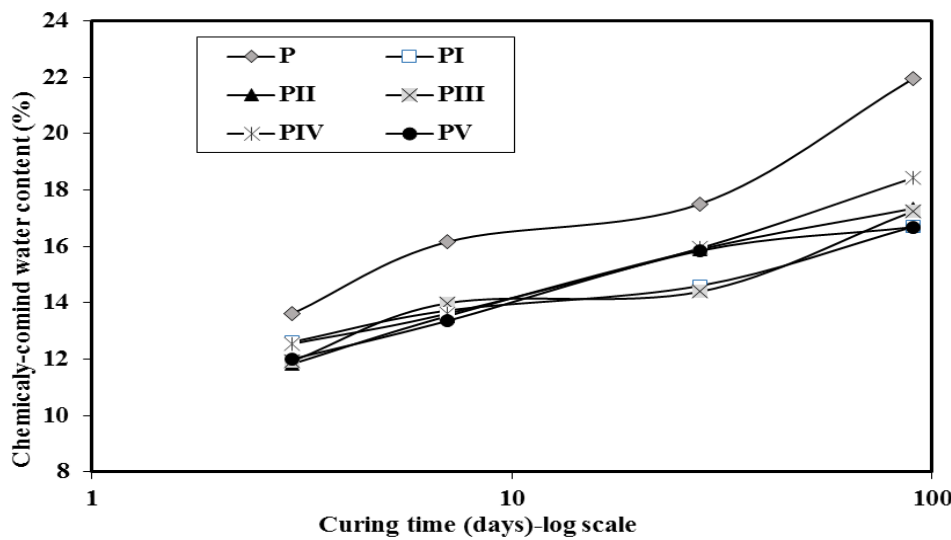

Figure 18. Chemically-combined water contents (Wn\%) hardened pastes made from mixes (PI-PV) containing thermally treated $\mathrm{PG}$ at $400{ }^{\circ} \mathrm{C}$ after $3,7,28$ and 90 days curing

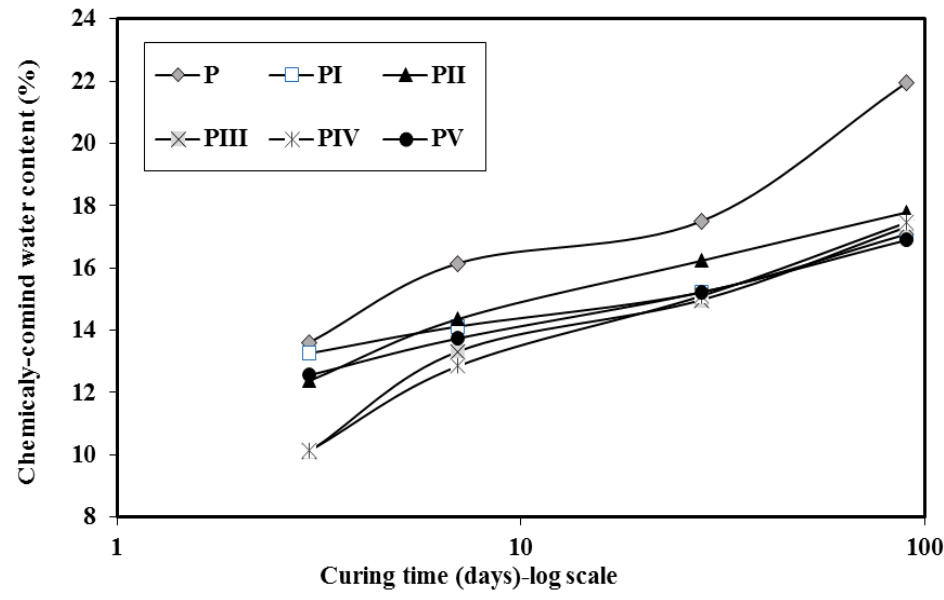

Figure 19. Chemicallycombined water contents (Wn\%) hardened pastes made from mixes (PI-PV) containing thermally treated $\mathrm{PG}$ at $600{ }^{\circ} \mathrm{C}$ after 3, 7, 28 and 90 days curing

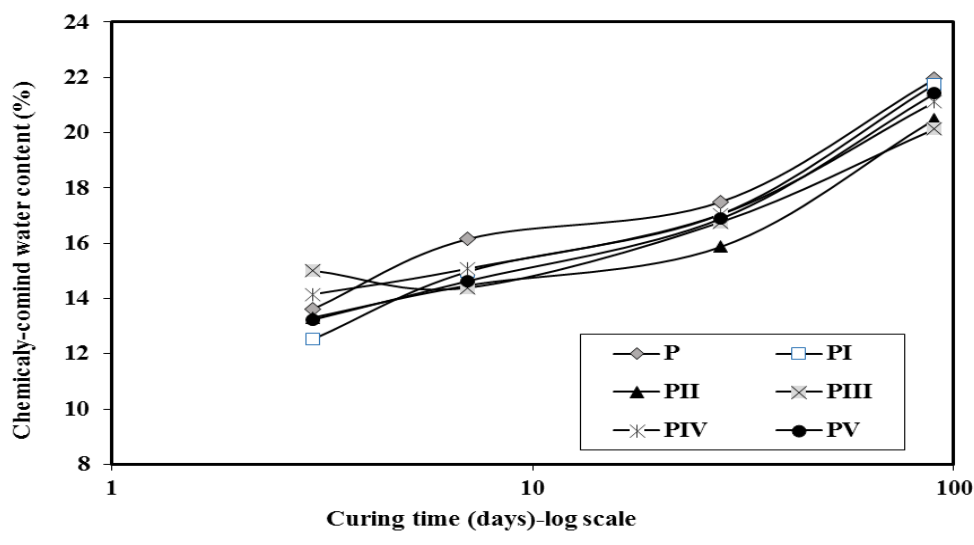

Figure. 20. Chemicallycombined water contents (Wn\%) hardened pastes made from mixes (PI-PV) containing thermally treated $\mathrm{PG}$ at $800{ }^{\circ} \mathrm{C}$ after 3, 7, 28 and 90 days curing

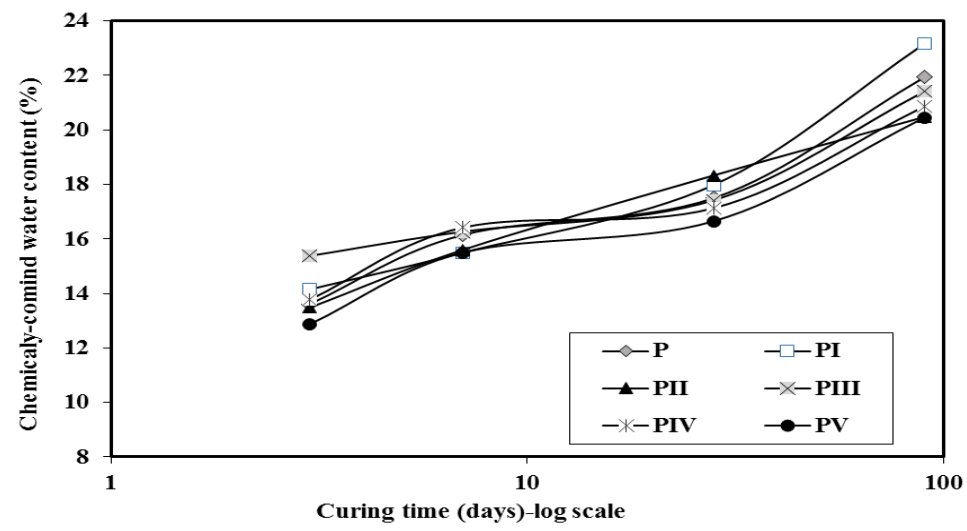


Figure 21. Chemicallycombined water contents $(\mathrm{Wn} \%)$ hardened pastes made from mixes (PI-PV) containing thermally treated $P G$ at $1000{ }^{\circ} \mathrm{C}$ after $3,7,28$ and 90 days curing

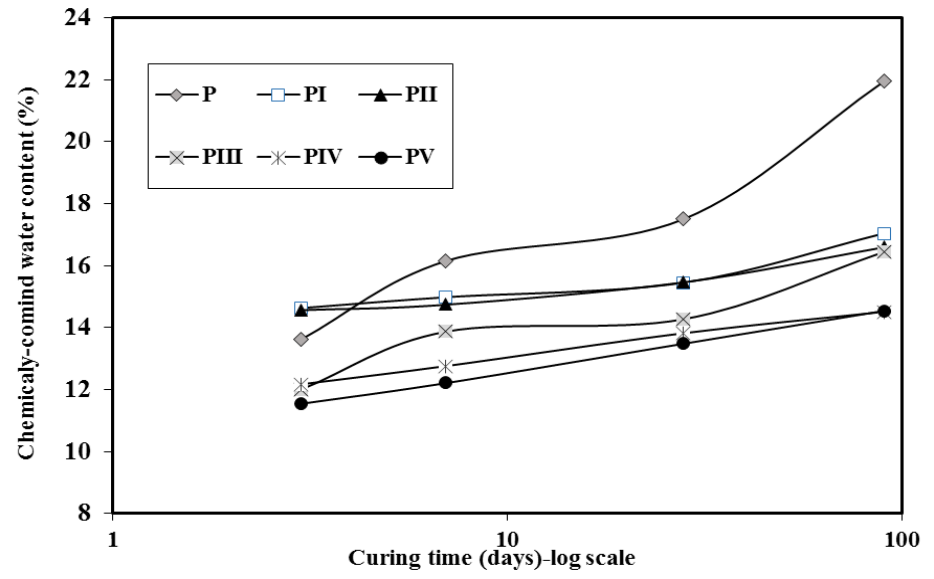

Free lime $(\mathrm{CaO} \%)$

Generally, the free lime content decrease with increasing curing time, so when the sample OPC contain raw gypsum, we found that, the free lime decreases by curing time but when the specimens OPC contain PG the free lime content increase by curing time. Figures 22,23, shown the free lime of pastes made from mixes (PI-PV) containing thermally treated $P G$ at different temperature ( 800 and $1000{ }^{\circ} \mathrm{C}$ ) after 3,7 , 28 and 90 days increasing with curing time due to $\mathrm{PG}$ containing $\%$ of $\mathrm{P}_{2} \mathrm{O}_{5}$ (6.79\%: $2.35 \%$ ) this lead to completely decomposition of $\mathrm{C}_{3} \mathrm{~S}$ into $\alpha{ }^{\wedge} \mathrm{H}-\mathrm{C}_{2} \mathrm{~S}$ and free lime content phases $[34,35]$.

\section{FTIR analysis}

The Infra-Red spectroscopy analysis was carried out on some selected samples of hardened pastes of mix (OPC) contain raw gypsum after 3,28 and 90 days curing, to identify the phases coexisting during hydration process which illustrated in Figure 24. It is clear that some bands appear at 3640, 3420, 1660 1460, 975, 875 and 505 $\mathrm{cm}^{-1}$. The formation of $\mathrm{C}_{2} \mathrm{~S}$ was accompanied by liberation of lime which gives absorption bands at $3640 \mathrm{~cm}^{-1}$ and $1460 \mathrm{~cm}^{-1}$ vibration of $\mathrm{OH}$ groups and $\mathrm{Ca}-\mathrm{O}$ stretching vibration appear sharp band at $3420 \mathrm{~cm}^{-1}$ this due to vibration of $\mathrm{HOH}$ groups and combined water. The formation of intermediate calcium silicate hydrate gives rise to strong absorption band at $975 \mathrm{~cm}^{-1}$ (vibration of $\mathrm{SiO}^{-4}$ groups). Calcite arising from partial carbonation of unreacted lime gives its absorption bands at $875 \mathrm{~cm}^{-1}$ [36]. The weak intensity band at $505 \mathrm{~cm}^{-1}$ is attributed to Si0 bending mode [37]. Figure 25. Illustrated the IR analysis of hydrated pastes of mix PV contain thermally treatment PG at $200{ }^{\circ} \mathrm{C}$ after 3, 28 and 90 days curing, There are different bands appear at intensities 3650, $3430,1660,1480,1110,970,870$ and 465 $\mathrm{cm}^{-1}$ the function group different by replacement raw gypsum by PG treated at $200{ }^{\circ} \mathrm{C}$ so, appear very sharp band at 3650 $\mathrm{cm}^{-1}$ this due to vibration of $\mathrm{OH}$ group of protlandite $(\mathrm{CH})$, and the water absorption bands appear at $3430 \mathrm{~cm}^{-1}$ and $1660 \mathrm{~cm}^{-1}$ [16]. The most significant infrared spectra of C-S-H contain a characteristic set of bands in the range 400-1200 $\mathrm{cm}^{-1}$. So, the weak band center at $1110 \mathrm{~cm}^{-1}$ this is due to attributed to asymmetric stretching frequency of Si-O$\mathrm{Si}$, on the contract, the broad band at 970 $\mathrm{cm}^{-1}$ which is due to vibration Si-O-Si [36], appear weak sharp band at $870 \mathrm{~cm}^{-1}$ this is due to calcite arising from partial carbonation of unreacted lime which gives this absorption band [38]. Finally appear weak band at $465 \mathrm{~cm}^{-1}$ this is due to the deformation of SiO4 tetrahedra [39]. 
Figure 22. Free lime contents (CaO\%) hardened pastes made from mixes (PI-PV) containing thermally treated PG at $800{ }^{\circ} \mathrm{C}$ after $3,7,28$ and 90 days curing

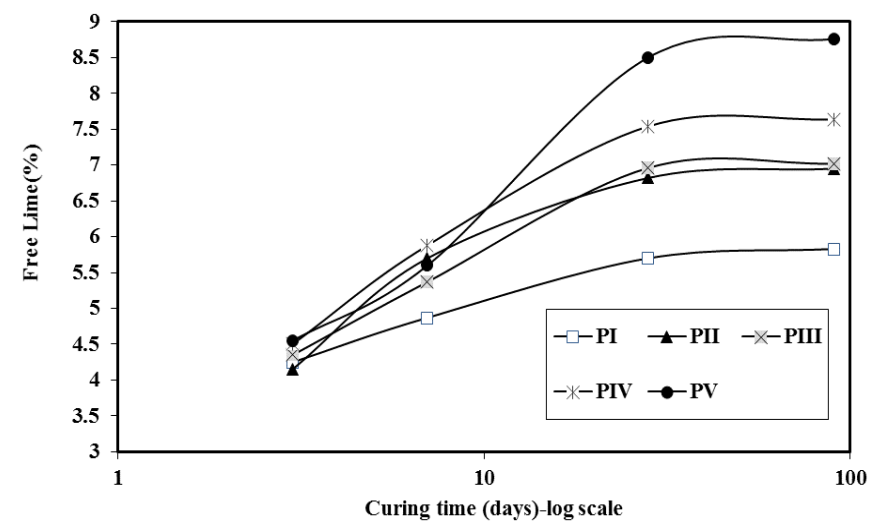

Figure 23. Free lime contents $(\mathrm{CaO} \%)$ hardened pastes made from mixes (PI-PV) containing thermally treated PG at $1000{ }^{\circ} \mathrm{C}$ after $3,7,28$ and 90 days curing

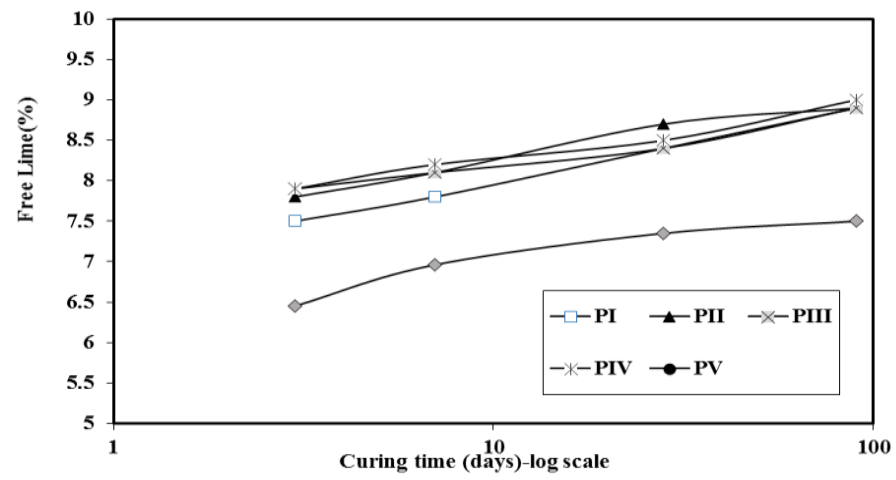

Figure 24. FTIR spectra of hardened pastes of OPC with RG after 3, 28 and 90 days curing

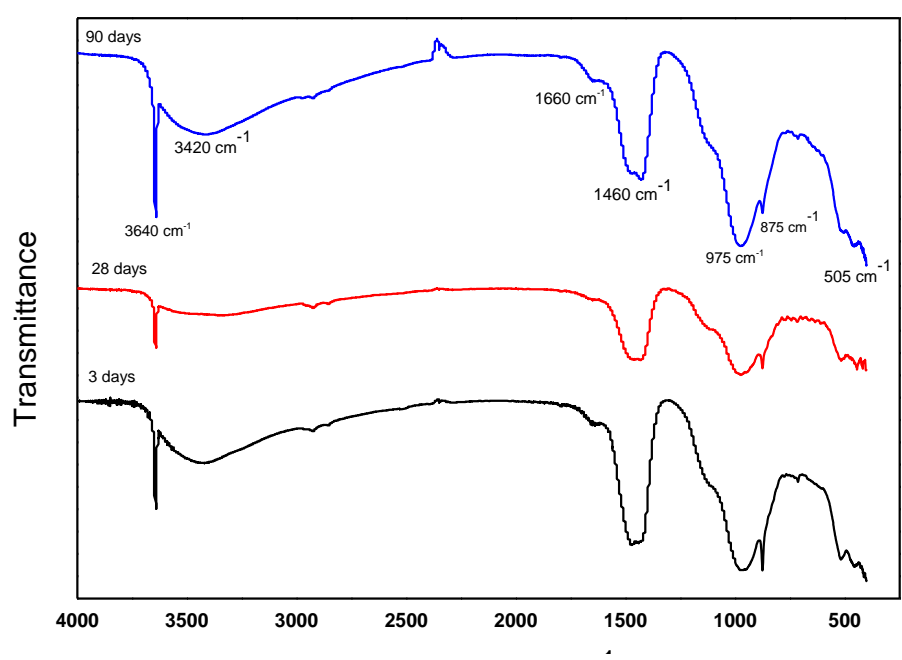

Figures 26,27 illustrated the IR spectra of hardened pastes of mix PV contain PG thermally treated at 600 and $1000{ }^{\circ} \mathrm{C}$ after 3, 28 and 90 days curing. There are some bands appear at $3643,3410,1660,1470,970,873$ and $464 \mathrm{~cm}^{-1}$ which are explained before. On the contract, $3643 \mathrm{~cm}^{-1}$ and $1436 \mathrm{~cm}^{-1}$ are due to formation of C2S accompanied by liberation of lime, $970 \mathrm{~cm}^{-1}$ is due to formation of intermediate calcium silicate hydrate and the intensity of $3643 \mathrm{~cm}^{-1}$ band decreased by increasing curing time due to more consuming of lime and high formation hydrated compound CSH so high compressive strength, the 1660 and $873 \mathrm{~cm}^{-1}$ intensity decreased by curing time which means decreasing of carbonation and increasing of calcium consuming causes increasing in formation of $\mathrm{CSH}$, high hydration properties. 
Figure 25. FTIR spectra of hardened pastes of mix OPC contain PG treated at $200 \mathrm{C}$ after 3, 28 and 90 days curing

Figure 26. FTIR spectra of hardened pastes of mix OPC contain PG treated at $600 \mathrm{C}$ after 3, 28 and 90 days curing

Figure 27. IR spectra of hardened pastes of mix OPC contain PG treated at $1000 \mathrm{C}$ after 3, 28 and 90 days curing
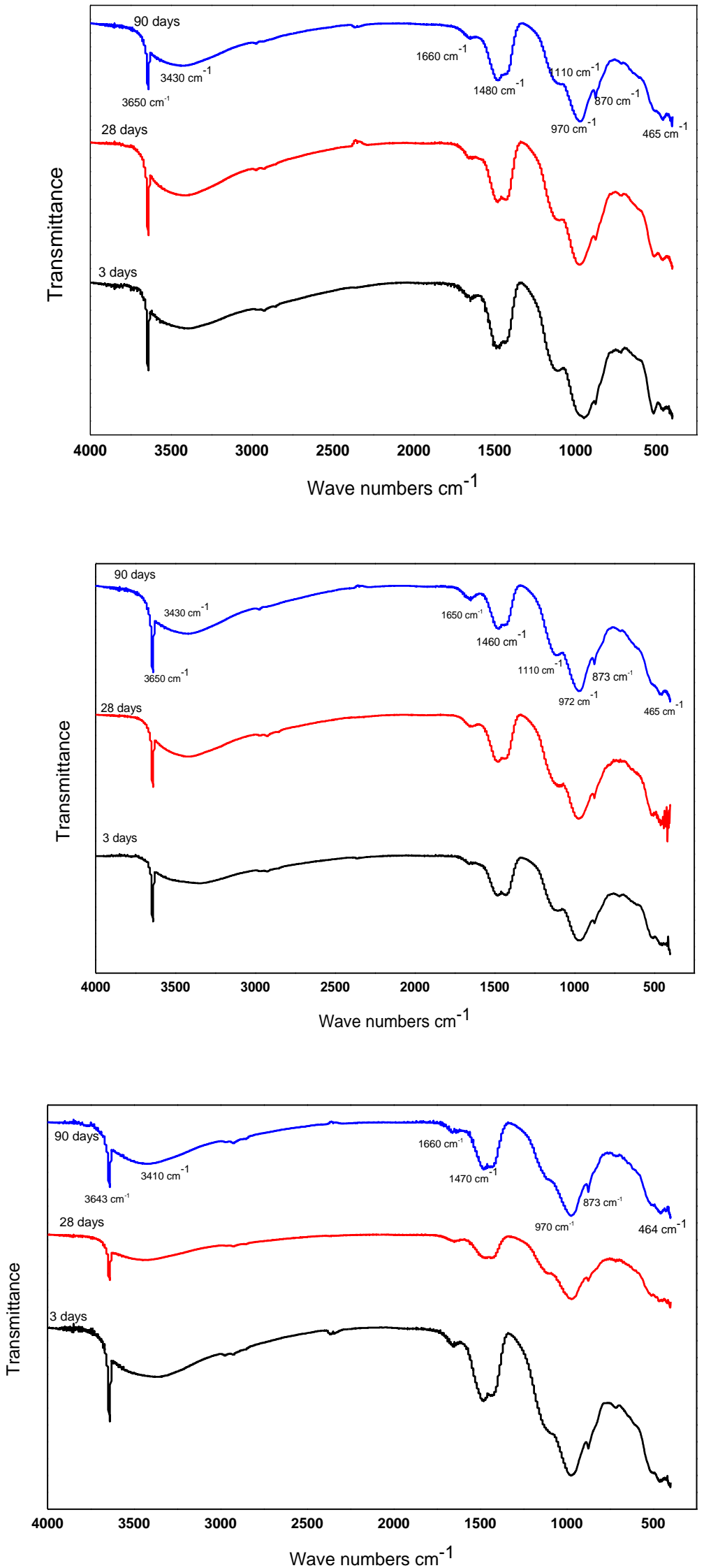


\section{Morphology and microstructure}

Hardened specimens of mix PV contain treated PG at 200, 600 and $1000{ }^{\circ} \mathrm{C}$ after 3 , 28 and 90 days curing, their SEM micrograph are shown in Figures 28-30. The SEM micrographs displayed the formation of various hydration products after 3 days a large amount of $\mathrm{Ca}(\mathrm{OH})_{2}$ crystals are generated after the reaction of $\mathrm{C} 3 \mathrm{~S}$ with water, the generation of $\mathrm{Ca}(\mathrm{OH})_{2}$ and $\mathrm{C}-\mathrm{S}-\mathrm{H}$ was observed. These are generated from the chemical bonding involving $\mathrm{Ca}^{2+}$ around the C3S particle. The hydration microcrystalline hexagonal crystals of monosulfate $\left(\mathrm{C}_{3}\right.$ A.CS. $\left.12 \mathrm{H}_{2} \mathrm{O}\right)$ and some calcium silicate hydrates ( $\mathrm{CSH}$ ), fibrous crystals of ettringite
$\left(\mathrm{C}_{3} \mathrm{~A} .3 \mathrm{CS} .32 \mathrm{H}_{2} \mathrm{O}\right)$ and Calcium hydroxide $\mathrm{Ca}$ $(\mathrm{OH})_{2}$. By continuous hydration of the pastes OPC- PG after 28 days the ettringite crystals are much and lead to changes in the morphology of the surface from hexagonal shape to more ettringite crystals. At 90 days the hydration there is decreasing in the porosity and formation of amorphous and ill-crystalline phase indicating increasing in the hydraulic properties of the pastes which there is increasing in the amorphous and illcrystalline phase with formation of closed texture phase indicating increasing in the hydraulic properties of the pastes. These results are in a good agreement with the obtained physico-chemical measurements of OPC-PG pastes [40].
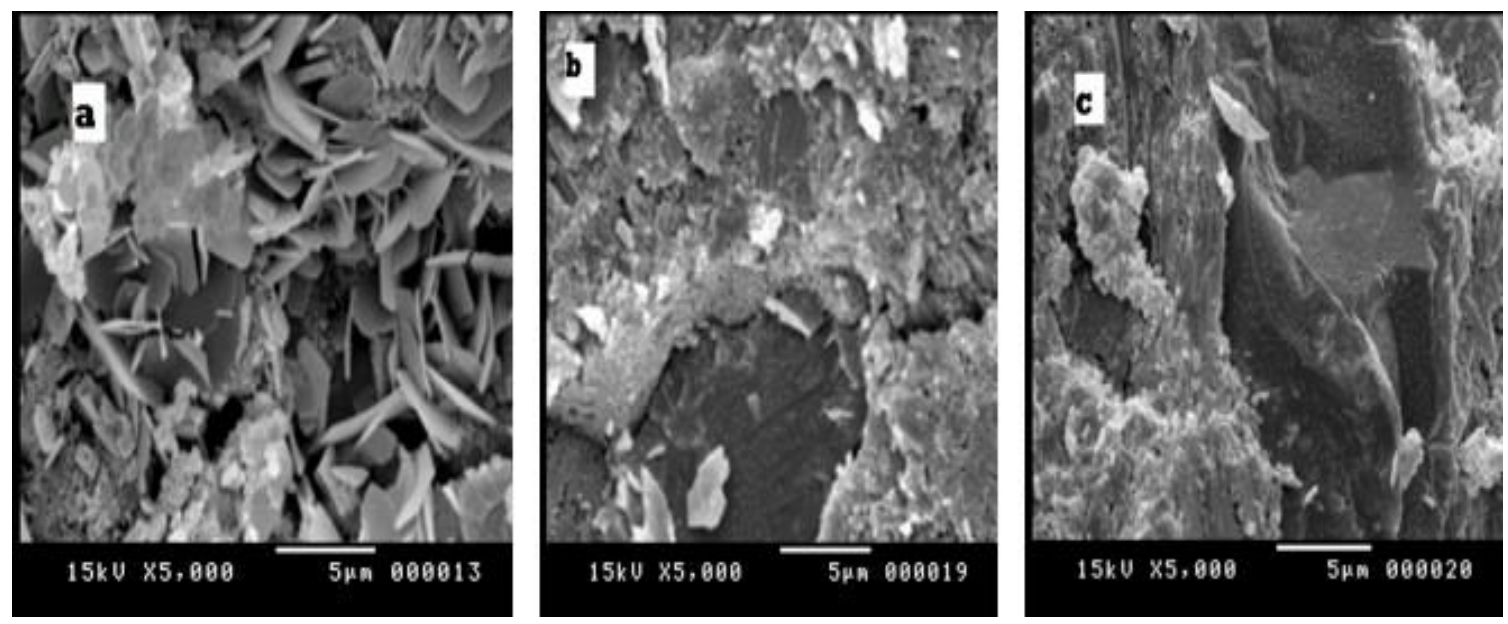

Figure 28. Micrographs of mixes (PV) contain thermally treatment $\mathrm{PG}$ at $200{ }^{\circ} \mathrm{C}$ after $3(\mathrm{a}), 28$ (b) and 90 (c), days curing
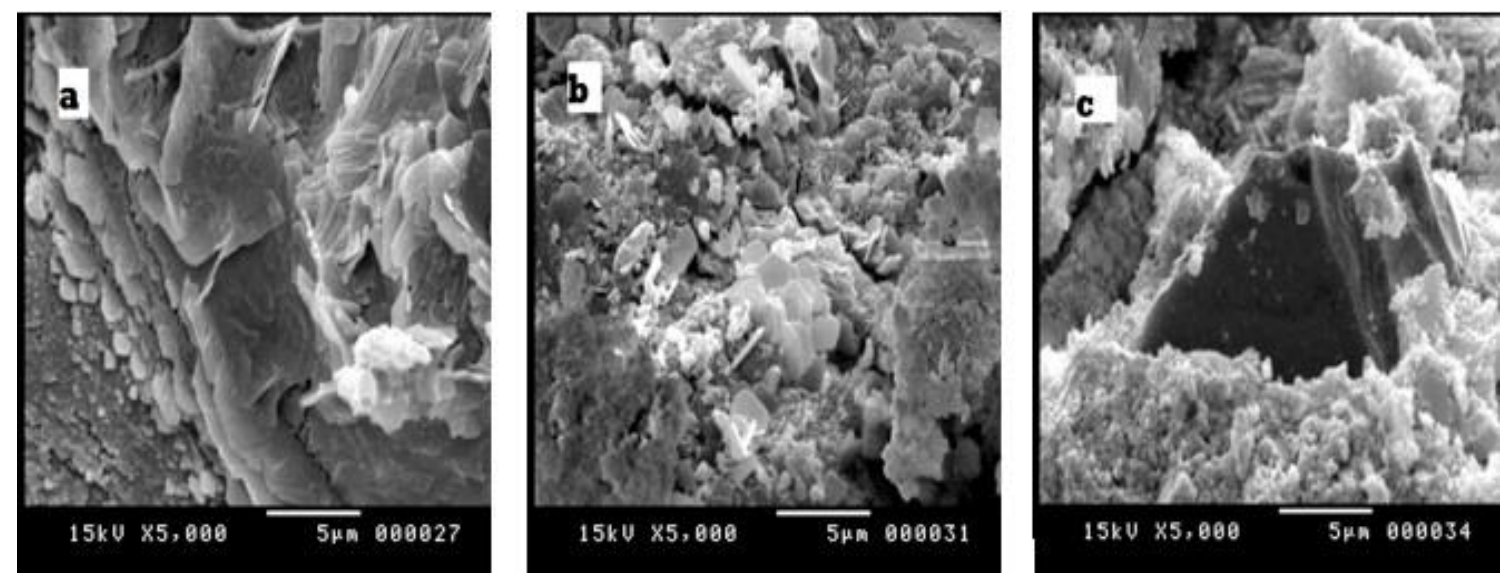

Figure 29. Micrographs of mixes (PV) contain thermally treatment $\mathrm{PG}$ at $600{ }^{\circ} \mathrm{C}$ after 3 (a), 28 (b) and 90 (c), days curing 

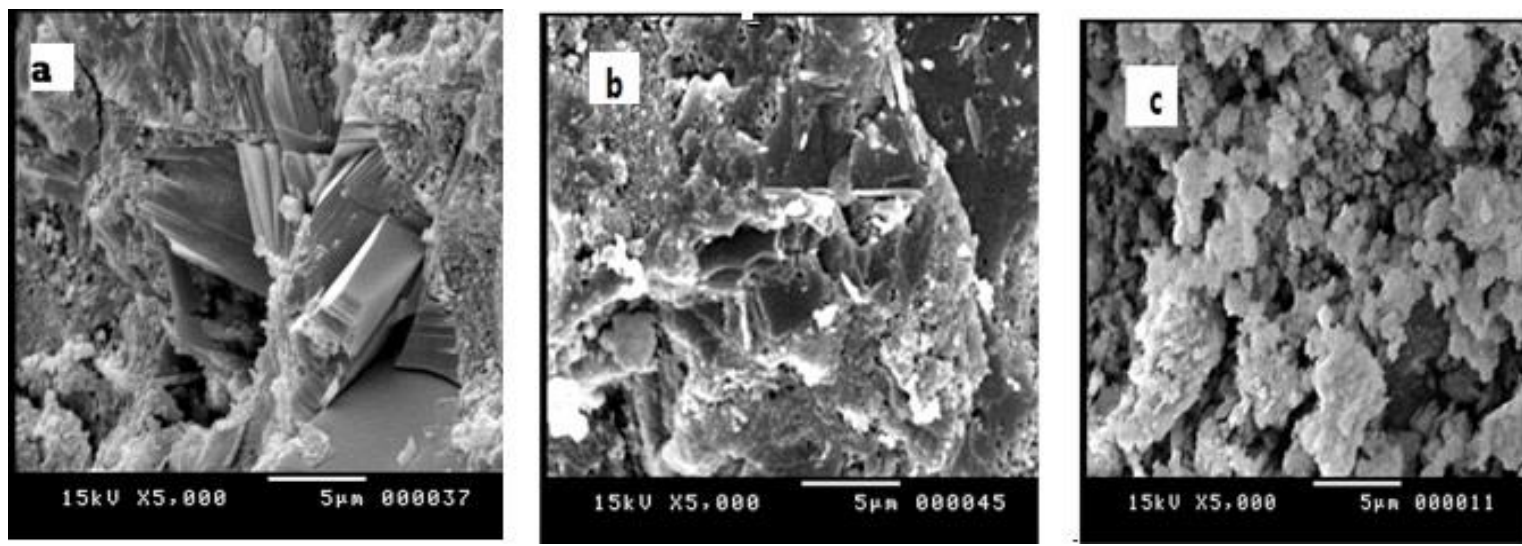

Figure 30. Micrographs of mixes (PV) contain thermally treatment $\mathrm{PG}$ at $1000^{\circ} \mathrm{C}$ after 3 (a), 28 (b), and 90 (c), days curing

\section{Conclusion}

From the above finding, it can be concluded that, the mechanical properties improvement by increasing the replacement of PG. So, the trends of the compressive strengths increases by increasing the firing temperatures of PG. The compressive strength of the various OPCPG pastes increases continuously with increasing age of hydration up to 90 days for all pastes. Mix PV (95\% PCC: 5\% PG treated at $1000{ }^{\circ} \mathrm{C}$ ) possesses the higher compressive strength values at all pastes and all time of curing, the optimum value of compressive strength for mix PV was at hardened pastes contains thermally treated $\mathrm{PG}$ at $1000^{\circ} \mathrm{C}$ after 90 days curing. Therefore, the suitable thermal treatment temperature for PG which yield a high hydraulic reactivity is $1000^{\circ} \mathrm{C}$. In comparison with mix PIII (95 \% PCC: 2\% RG: $3 \%$ PG treated at $200{ }^{\circ} \mathrm{C}$, possess the lowest compressive strength values at all pastes and all time of curing. From all experimental the higher values of compressive strength at mixes contain PG treated at $(400,600,800$, $\left.1000{ }^{\circ} \mathrm{C}\right)$.

\section{Acknowledgement}

The author is thankful to team of Manaseer Cement Factory for helping to execution of these experiments.

\section{Disclosure statement}

No potential conflict of interest was reported by the authors.

\section{ORCID}

Mahmoud A. Taher (D): 11133444876585

\section{References}

[1] A. Arman, R.K. Seals, Proc., Int. Symp. on Phosphogypsum, FIPR, Orlando, FL, 1990, pp 562-575.

[2] USEPA, Final Rep., United States Environmental Protection Agency, 1992.

[3] F. Ferguson, Florida Institute of Phosphate Research, 1988, 117-130.

[4] R. A. Sam, S. A. Bamford, J. J. Fletcher , F. G. Ofosu, A. Fuseini, Int. J. Sci. Technol., 2013, 2, 252-258.

[5] A. M. Neville, J.J. Brooks, Concrete technology England: Longman Scientific \& Technical. 1987, pp 242-246.

[6] E.M. Van der Merwe, C.A Strydom, South Afr. J. Sci., 2004, 100, 411-414.

[7] M. Singh. Cement Concrete Res., 2002, 32, 1033-1038.

[8] S. Manjit. Cement Concrete Res., 2003, 31, 1363-1369.

[9] S. Manjit. Construct. Build. Mater., 2005, 19, 480-486. 
[10] J.H. Potgieter, S.S. Potgieter, R.I. McCrindle, C.A. Cement Concrete Res., 2003, 33, 1223-1227.

[11] I.A. Altuna, Y. Sert, Cement Concrete Res., 2004, 34, 677-680.

[12] L. Kacimi, A. Simon-Masseron, Z. Derriche, J. hazard. Mater., 2006, 137, 129137.

[13] H. Tayibi, M. Choura, F.A. López, F.J. Alguacil, A.L. Delgado, J. Environ. Manag., 2009, 90, 2377-86

[14] M. Yang, J. Qianand, Y. Pang, Construct. Build. Mater., 2008, 22, 1004-1008.

[15] M.A. Taher, Resour. Conserv. Recy., 2007, 52, 28-38.

[16] S. Manjit, M. Garg, Cement Concrete Res., 2000, 30, 571-577.

[17] M.M. Smadi, R.H. Haddad, A.M. Akour, Potential use of phosphogypsum in concrete", Cement Concrete Res., 1999, 29, 1419-1425.

[18] C. Papastefanou, S. Stoulos, A. Ioannidou, M. Manolopoulou, J. Environ. Radioact., 2006, 89, 188-198.

[19] J.P. Bolivar, R. Garcia-Tenorio, F. Vaca, Pregamon, 2000, 2941-2950.

[20] T. Reddya, D. Siva Sankar, R. Kumarb, H. Sudarsana Raoc. Asian J. Civil Eng., 2010, 11, 411-420.

[21] H. El Nouhy, E. Khattab, S. Zeedan, Key Eng. Mater., 2016, 668, 181-188.

[22] G.M. Sadiqul Islama, F.H. Chowdhurya, M.T. Raihana, S.K. Sikder Amita, M.R. Islama, Proced. Eng., 2017, 171, 744-751.

[23] M.A. Taher, A.M. Amine, B.K. Damarany, Adv. J. Chem. Section A, 2019, 2, 296-315

[24] British European Standard BS EN-196-1: Methods of testing cement. Determination of strength, 2005.

[25] British European Standard BS EN-196-3: Methods of testing cement. Determination of setting times and soundness, 2005.
[26] M. Abd El Aziz, S. Abd El Aleem, M. Heikal, H. El Dizdamony, Cement Concrete Res., 2005, 35, 1592-1600.

[27] H. El-Didamony, S.A. Abo-El-Enein, M.Y. Haggag, Cement Concrete Res., 1978, 8, 351-358.

[28] M.P. Javellana, I. Jawed, Cement Concrete Res., 1982, 12, 399-403.

[29] M.S. Al-Hwaiti. Bangladesh J. Sci. Ind. Res., 2015, 50, 241-250.

[30] E. Erdem, H. Ölmez, Cement Concrete Res., 1993, 23, 115-121.

[31] H. He, P. Stroeven, E. Pirard, L. Courard, Key Eng. Mater., 2012, 331-337.

[32] A.H Asbridge, G.A Chadbourn, C.L. Cement Concrete Res., 2001, 31, 1567-72.

[33] W. Teck-Kwon, K. Young-Hee, C. Yong-Sik, L. Jong-Kyu, I. Seob-Kim, S. RyongKim, Adv. Technol. Mater. Mater. Process., 2005, 7, 63-66.

[34] K.T. Lin, W.F. Chang, Strength properties of compacted phosphogypsum-based mixtures, Volume II. In proceedings of the second International symposium on phosphogypsum, University of Miami, Florida Institute of Phosphate Research, Bartow, Florida, 1988, pp 239-254.

[35] L. Kacimi, A. Simon-Masseron, Z. Derriche, J. hazard. Mater., 2006, 137, 129137.

[36] M.N. de Noirfontaine, S. Tusseau-Nenez, M. Signes-Frehel, G. Gasecki, C. GirodLabianca, J. Am. Ceram. Soc., 2009, 92, 2337-2344.

[37] F.A. Rodrigues, Am. Chem. Soc., 1999, 39, 30-31.

[38] W. Eitel, Silicate Science, Volume I: Silicate Structures, Academic Press, New York, NY, USA, 1964.

[39] H. B“oke, O. Cizer, B. Ipeko glu, E. U`gurlu, K. S,erifaki, G. Toprak, Construct. Build. Mater., 2008, 22, 866-874.

[40] M.A. Tantway, Res. Bull., 2015, 61, 415-421.

How to cite this manuscript: Mahmoud Ahmed Taher, Adel Mohamed Amine, Bassam Khalaf Damarany, Physico-Chemical Properties of Ordinary Portland Cement Pastes after Partial Substitution of Gypsum With Thermally Treatment Phosphogypsum, Adv. J. Chem. A, 2020, 3(3), 301-317. 